\section{IJßER}

ISSN: 2149-5939
International Journal of Social Sciences and Education Research

Online, http://dergipark.gov.tr/ijsser

Volume: 3(1), 2017

\title{
Information literacy: Educate through literacy
}

\author{
Nur Amanah Ilham Atjo ${ }^{1} \quad$ Muhammad Fadhil Pratama $^{2}$
}

Received Date: 03 / 09 / 2016

Accepted Date: 12 / 11 / 2016

\begin{abstract}
The concepts and terms about "Information Literacy" has become general study in education studies. Information literacy is pivotal in this global world where the information literacy equip a person's ability to access, understand and use the information intelligently. In higher education, in the learning process, students should be able to get used to a new way in education. Students must independently by finding, training themselves and absorbing the education material from lecturers. The development of highly advanced information technology has resulted the explosion of information so every student receives any information and from anywhere without limits and filters. Therefore, every student is required to have the ability to fulfill the information needs which is called "Information Literacy". School of literacy implemented by Podjok Baca community aims to educate students so that they have the literacy skills because it is one of the basic needs to survive in the information age. In order to successfully fulfilling the need for information, it would require an understanding of information literacy through School of Literacy. Information literacy regarded as a very important skill and the key in solving problems which is known as "Problem Solving and Decision Making Skills". This paper focusing on school of literacy activities by Podjok Baca Community which aims to know how far the application of "Problem Solving and Decision Making Skills" in information literacy.
\end{abstract}

Keywords: Educate, information literacy, school of literacy, skills, technology

\section{Introduction}

Literacy is derived from the Latin "Littera" (letters) that are mainly related to language and how language is used. Simply, literacy can be defined as an ability to read and write. Kern (2000) defines the term literacy comprehensively as follows:

"Literacy is the use of socially-, and historically-, and culturally situated practices of creating and interpreting meaning through texts. It entails at least a tacit awareness of the relationships between textual conventions and their context of use and, ideally, the ability to reflect critically on those relationships. Because it is purpose-sensitive, literacy is dynamic - not static - and variable across and within discourse communities and cultures. It draws on a wide range of cognitive abilities, on knowledge of written and spoken language, on knowledge of genres, and on cultural knowledge"

Literacy includes some language skills, including proficiency in listening, speaking, reading and writing. Literacy is also composed of various models such as computer literacy, media literacy, technology literacy, economic literacy, information literacy, there is even a moral literacy. If someone can understand something by reading the right information and do something based on his understanding of the content of the reading, it can be regarded as a person who "Literat".

\footnotetext{
${ }^{1}$ Universitas Islam Indonesia, INDONESIA, amanahilhamatjo@yahoo.com

${ }^{2}$ Universitas Islam Indonesia, INDONESIA, fadhilopratama@yahoo.com
} 
The technology basically allows us to obtain the information we need. In the development of science and technology rapidly, that direct these developments led to increasing amounts of information. Various kinds of information conveyed in various ways and we realize our lives are surrounded by hundreds or even thousands of information. With so much information available, not all such information is the information we need, therefore, needed an ability to choose the information that we really need. The ability is called "Information Literacy"

Information literacy can be taught through literacy education. Educate through literacy is one way that aims to get someone seeking information in accordance with their respective needs. Literacy skills is an ability that is longlife learning. Therefore, the literacy skills continuously useful orientation that can be used in social life, especially in problem solving and decision making.

One of literacy education activities that can be done is school of literacy. Podjok Baca Community as one community of Reading Movement at the Faculty of Economics, Universitas Islam Indonesia and also initiator School of Literacy activities were originally formed because of concerns of a lack of literacy among the community. With the movement to educate through this literacy is directed and given an understanding of literacy. How individuals manage and receive the information they need through a variety of media and is also a producer of information for himself.

\section{Purpose}

This paper purpose to determine the extent of the application of the "Problem Solving and Decision Making Skills" in literacy, especially school of literacy activities conducted by Podjok Baca Community.

\section{Method}

The research method used by writer is descriptive analytic method, which the author gives an explanation of the information literacy, such as what the literacy education and the application of the "Problem Solving and Decision Making Skills" in information literacy. The data that use in this study are primary data obtained through interviews and secondary data is data obtained from books, articles published of going to press, the Internet and so forth relating to the problems examined.

\section{Information literacy}

Information literacy was first discovered by the American Information Industry Association leader Paul G.Zurkowski in 1974 in a proposal addressed to the National Commission on Libraries and Information Science (NCLIS) in the United States. Paul Zurkowski used the phrase to describe the information literacy "technique and ability" which is known as information literacy is the ability to utilize a wide range of information tools and sources of primary information to solve their problems. 
Atjo, N.A.I., Pratama, M.F. (2017). Information literacy: Educate through literacy. International Journal of

Social Sciences and Education Research, 3(1), 35-57.

American Library Association (ALA) defines information literacy as follows:

Information literacy is a set of abilities requiring individuals to Recognize when information is needed and have the ability to locate, Evaluate, and effective use needed information". (Http://www.ala.org/acrl/standards/informationliteracycompetency\#ildef, Accessed 20 September 2016).

ALA also stated that information literacy is one of the important components that should be owned by every citizen and contribute in achieving lifelong learning. Information literacy is considered as one of the most important studies in the world of information literacy education is needed in the social life of a society where communication process runs must contain information that is disseminated. The information provided there is the necessary and some are not required therefore the literacy skills must be imparted to every individual since the information literacy lasted a lifetime. Information literacy emphasize that each individual has the intellectual ability to think critically and argue, and learn how to learn. That is the cause of information literacy has always been associated with lifelong learning. Information literacy is useful to increase the community's ability to evaluate, organize and use information.

According to Chan Chin Yuen (2001: 1):

a. Information literacy is crucial to the success of lifelong learning.

b. Information literacy is a core competency in the information age.

c. Information literacy contributes to the development of teaching and learning.

As the first to use the concept of information literacy, Zurkowski states that people who are trained to use sources of information in completing the task they are called literate information. They have studied the techniques and the ability to use the tools and the main source of information in solving their problems (Behrens, 1994: 310). Then, according to Jan Olsen and Coons in Behrens (1994: 313) view of information literacy with broader coverage. They define the information literacy as understanding the role and power of information, namely: has the ability to find, redial information; use it in decision making; and has the ability to generate and manipulate information using electronic processes.

Some views and understanding of the information literacy of researchers, we can see that meaning of literacy is the most widely accepted is the view that information literacy is a combination of skill, attitude and knowledge.

Information literacy models that have been widely adopted as a model seven pillars, as follows: 
Atjo, N.A.I., Pratama, M.F. (2017). Information literacy: Educate through literacy. International Journal of Social Sciences and Education Research, 3(1), 1-8.

Figure 1. Model Seven Pillars

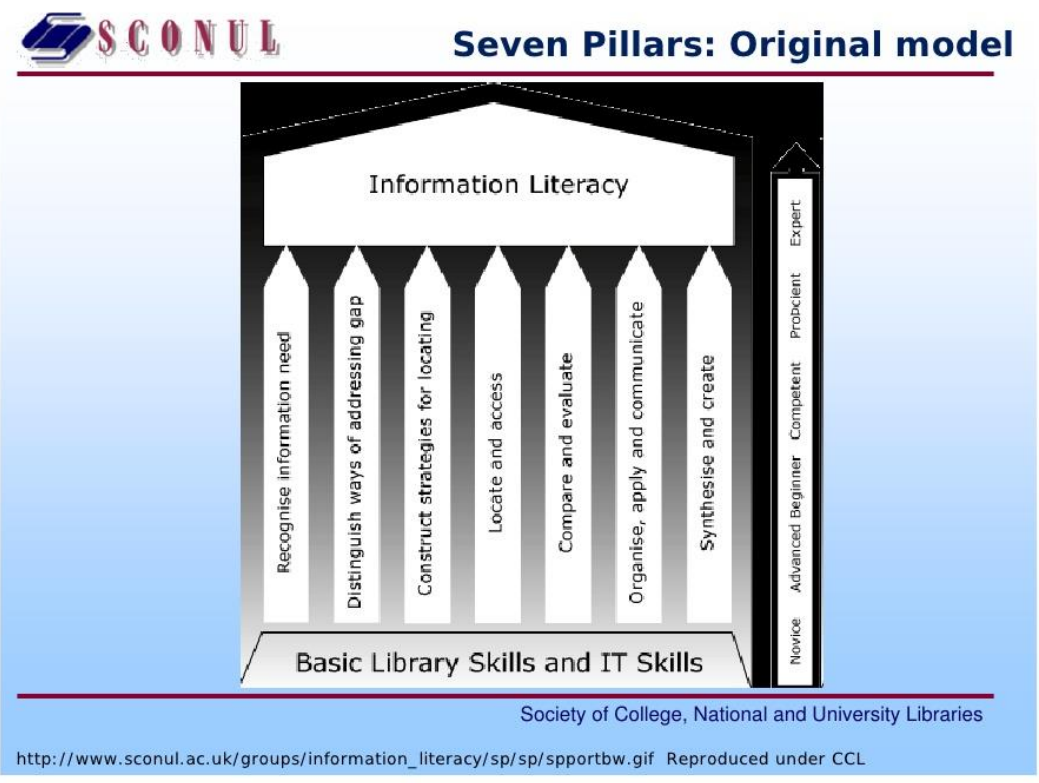

Model Seven Pillar consists of two sets of skills and the 7 pillars, namely:

1. The ability to recognize and identify the information that is really needed

2. The ability to distinguish the way in addressing the information gap

3. Ability to develop strategies to find information

4. The ability to locate and access information

5. The ability of to compare and evaluate information

6. The ability to organize, use and communicate information to others in a manner appropriate to the situation

7. The ability to combine and build existing information, as input to create new knowledge.

From these explanations, information literacy is closely related to the ability to think critically and a sensitivity to all aspects of life. Information literacy requires an individual to have the ability to analyze the information to be used appropriately in solving the problem. Information literacy is not only related to access to information, but rather the process of forming a person become lifelong learners.

\section{School of literacy by Podjok Baca Community}

School of literacy is one of the activities carried out by Podjok Baca Community, Faculty of Economics Universitas Islam Indonesia in cooperation with the Rumah Baca Komunitas. Podjok Baca Community was formed because of concerns of a lack of literacy among students. Given the results of the study Programme for International Student Assessment (PISA) mentions that the literate culture of Indonesian people in 2012, the second worst of the 65 countries surveyed in the world. Indonesia ranks 64 out of 65 countries. While Vietnam it ranks the top 20 (http://www.femina.co.id/trending-topic/peringkat-literasi-indonesia-nomor-dua-daribawah, Accessed 20 September 2016). 
Atjo, N.A.I., Pratama, M.F. (2017). Information literacy: Educate through literacy. International Journal of

Social Sciences and Education Research, 3(1), 35-57.

Data from the Human Development Index (HDI) of 2011 issued by the United Nations Development Program (UNDP) based on illiteracy showed that Indonesia was ranked 124 of 187 countries in the world. This rating is lower than the five other ASEAN countries, namely Singapore (26), Brunei (33), Malaysia (61), Thailand (103), and the Philippines (112). However, Indonesia remains higher over Vietnam (128), Laos (138), Cambodia (139), and Myanmar (149) (http://hdr.undp.org/en/statistics/, Accessed 20 September 2016). Meanwhile, according to data from the Central Statistics Agency (BPS) in 2006, showed that people are more interested in and chooses to watch television (TV) (85.9\%) or listen to the radio (40.3\%) than reading newspapers $(23.5 \%)$ (http://bpad-kepri.pnri.go.id/content/andy-f-noya-duta-baca-indonesia, Accessed 20 September 2016). The data showed low interest in reading Indonesian people.

Another fact that is found from the research data UNESCO in 2012 which stated that Indonesia's population of 1000 people, only one person who has interest in reading with an index of 0.001 percent. Therefore, Podjok Baca Community formed to start opening the book stall in the Central Hall of the Faculty of Economics Universitas Islam Indonesia to invite students to read books that are available and can borrow the book. Then, another agenda by Podjok Baca Community is conducting Educational Literacy which aim to encourage students to develop interest in reading through the book, provide insight to students about what is literacy, why literacy is important in life, how to choose the appropriate information needs through literacy remember information that exist around more because of technological developments then one should be critical in the use of such information in accordance with the needs.

School of literacy emphasizes that literacy is not just synonymous with reading and writing but also how to get along information through any medium through newspapers, magazines, books, and even electronic media like television, radio, and internet. According to Wells (1987) states that there are four levels of literacy, namely: Performative, Functional, Informational, and Epistemic. On the literacy level of performative, a person is able to read and write, and speak to the symbols used (language). At the level of functional literacy, a person is expected to use the language to meet the daily life such as reading manuals. Then informational literacy level, a person is expected to access the knowledge of the language. While the literacy epistemic level, someone can transform knowledge in the language.

\section{Problem solving and decision making skills in literacy}

The skills are needed to meet the information needs are considered to work not only in libraries or educational issues, but the information literacy is an important issue in the development of economic, health, social, and improving the quality of human life. Therefore, these skills should be owned by every individual. skills in literacy mainly used in problem solving and decision making which is called "Problem Solving and Decision Making Skills". Application of "Problem Solving and Decision Making Skills" This leads to how one is literate. Individuals who have this literate usually have self-confidence, self-reliance, initiative, and have a high motivation to perform various activities. Then, the individual knows how to learn and will continue to explore ways to implement lifelong learning.

In the information age, literacy can be regarded as human rights. School of literacy conducted in order to shape a generation which literat. The students can understand how traffic congestion information at this time so they need information literacy skills. Students who are 
Atjo, N.A.I., Pratama, M.F. (2017). Information literacy: Educate through literacy. International Journal of Social Sciences and Education Research, 3(1), 1-8.

implement the "Problem Solving and Decision Maing Skills" them to survive in the information age. the application of these skills typically use models of literacy "The Big 6 (An Information Problem-Solving Process)". Literacy model was developed by two experts named Robert E. Berkowitz and Michael B. Eisenberg in 1987. Berkowitz and Eisenberg named the model of information literacy with the Big 6. literacy model has been widely used around the world including the United States, Italy, Netherlands, South Africa, Taiwan, New Zealand and Indonesia.

The Big 6 consists of six skills and 12 steps. Each skill has several steps:

1. Task define

- Define the information problem

- Identify information needed

2. Information Seeking Strategies

- Determine all possible sources

- Select the best sources

3. Location and Access

- Locate sources (intellectually and physically)

- Find information within sources

4. Use of Information

- Engage (e.g., read, hear, view, touch)

- Extract relevant information

5. Synthesis

- Organize from multiple sources

- Present the information

6. Evaluation

- Judge the product (effectiveness)

- Judge the process (efficiency) (Eisenberg, 2004: 1)

Based on the explanation, the model of literacy The Big 6 has six skill is to formulate the problem through information search strategy that includes determining and selecting the appropriate resources; then allocate and access the information that is needed for example OPAC information search tool; after that utilize the information that can be done by reading, hearing, touching; then synthesize the information that can be done by way of organizing and present the information, and the last is to evaluate the information, in evaluating the results seen in effectiveness and process that is efficiency.

The students were educated through literacy implement the "Problem Solving and Decision Making Skills" by using the model of The Big 6. Model the big 6 is a very good use in solving problems, execution of tasks and decision making. They apply "Problem Solving and Decision Making Skills" not only in academic activities both homework but also in daily life because 
Atjo, N.A.I., Pratama, M.F. (2017). Information literacy: Educate through literacy. International Journal of

Social Sciences and Education Research, 3(1), 35-57.

the accumulated information that exists today. They were able to exploit a wide range of information to make decisions on target.

\section{Conclusion}

Information literacy is a process of empowering someone in every course of his life to seek, evaluate, use and create information effectively to achieve their personal, social, occupational, educational, and other purposes. As one needs to survive in this information age, information literacy plays a very important in any case. In essence, the basic foundation of information literacy into the longlife learning that is why the two concepts are closely related and can not be separated from one another.

The concept of information literacy and longlife learning makes people keep trying to survive with flooded information that is constantly evolving in today's information era. In Indonesia, literate culture is still relatively poor communities where they do not have the awareness of the importance of literacy skills, especially in information literacy. Seeing these facts, the instigators of the literacy movement to initiate any activity whose purpose is to increase public interest in literacy, especially students with schools implementing literacy. With school of literacy, students are introduced on the urgency of literacy itself then directed to increase their reading fluency because with this literacy skills a person can survive in the information age.

Individuals who are educated through literacy will always be aware that literacy is very important in the social life of society. Individuals who have the literacy skills can be said as an individual who literate where he will always be critical in receiving, managing and using information around. Of course they also have skills in problem solving and decision making. When somenone is aware of the information that really he needs, the adoption of "Problem Solving and Decision Making Skills" that he has to be very effectively used when it is in trouble.

Literacy education would be expected to be applied in every activity of the community activities given that information literacy is not only within the scope of education, but has been linked with other aspects in the sphere of social life. Because literat society is a society that is able to exploit a wide range of information to solve problems and make the right decision.

\section{References}

Association of College \& Research Library, Information Literacy Competency Standards for Higher Education, through http://www.ala.org/acrl/standards/informationliteracycompetency\#ildef (Accessed 20 September 2016).

Badan Perpustakaan dan Arsip Daerah Kepulauan Riau, Andy F Noya Duta Baca Indonesia, through http://bpad-kepri.pnri.go.id/content/andy-f-noya-duta-baca-indonesia (Accessed 20 September 2016).।

Behrens, Shirley J. (1994). "A Conceptual Analysis and Historical Overview of Information Literacy." College \& Research Libraries 56 : 309 - 322.

Chan Yuen Chin, Mandy. (2001) Rethinking Information Literacy - A Study of Hong Kong University Students through http://www.cite.hku.hk/events/citers2003/Archive/MSc_presentation/MandyChanCITERS03.ppt (Accessed 20 September 2016); 1-8.

Einsberg, M, Lowe, C.A, Spitzer, K.L. (2004). Information Literacy: Essential Skills For The Information Age. Connecticut: Libraries Unlimited. 
Atjo, N.A.I., Pratama, M.F. (2017). Information literacy: Educate through literacy. International Journal of Social Sciences and Education Research, 3(1), 1-8.

Femina, Peringkat Literasi Indonesia, Nomor Dua Dari Bawah, through http://www.femina.co.id/trending-topic/peringkat-literasi-indonesia-nomor-dua-dari-bawah (Accessed 20 September 2016).

Kern, R. (2000). Literacy and Language Teaching. Oxford: Oxford University Press.

UNDP, Human Development Data (1980-2015), through http://hdr.undp.org/en/statistics/ (Accessed 20 September 2016).

Wells, B. (1987). “Apprenticeship in Literacy.” Interchange 18,1/2:109-123. 